\title{
FUNGSI YUDISIAL UNTUK MENJAGA KEMANDIRIAN HAKIM DALAM SISTEM PERADILAN PIDANA
}

\author{
Kraisus Sitanggang*) \\ Kraisus.sitanggang@uki.ac.id \\ Fakultas Hukum, Universitas Kristen Indonesia
}

\begin{abstract}
Abstrak
Indonesia is a state law that has been declared in the constitution, as a country that upholds the law, will be established justice agencies to resolve those cases that occur in the community, one of them is the court, the court is part of the criminal justice system, where the court is the place to examine the case, which the judge who became breaker guilty or not a person, as law enforcement, judges should be is independent in deciding a case, where the decision was not impartial and free from political influence and power, and free from bribes though, that the independence of judges independent and impartial influence, it needs to be maintained and protected, the reality in the Indonesian constitution in the constitution in 1945 through an amendment, it has been maintained and is watching her body established the Commission on judicial and law on judicial power, its purpose is enable the independence and freedom of judges in deciding a case, in order to obtain a legal justice, which is guaranteeing protection of the rights of justice seekers and that is where it is said that Indonesia is a country of law.
\end{abstract}

\section{Kata Kunci : Fungsi Yudisial untuk menjaga kemandirian hakim}

\section{Pendahuluan}

Indonesia adalah Negara Hukum, demikian dinyatakan pada kontitusi Undang-undang Dasar 1945. Sebagai suatu Negara Hukum, Indonesia menghendaki agar segala gerak gerik dan perilaku warga negara, pejabat negara serta aparat penegak hukum, harus berdasarkan hukum atau peraturan perundangundangan yang berlaku. seseorang dinyatakan bersalah, harus berdasarkan hukum, begitupula bila seseorang hendak dikenakan upaya paksa harus lah berdasarkan hukum tertulis, dengan demikian hukum adalah diatas segala-galanya.

Untuk mengimplementasikan serta menjalankan Hukum, dibentuklah yang namanya badan peradilan, salah satunya sistem Peradilan Pidana. Badan inilah yang menseleksi apakah seseorang itu memenuhi unsur-unsur Tindak pidana. bila memenuhi, maka dapat dijatuhkan sanksi berupa pidana. bila tidak ditemukan kesalahan, maka harus dibebaskan. Sebagai suatu badan peradilan yang salah satu bagiannya adalah Pengadilan, yang dalam hal ini adalah Hakim. Sebagai seorang Hakim, maka perannya sangat penting karena dialah yang memiliki tugas dan wewenang untuk menyatakan seorang warga negara itu bersalah atau tidak. Begitu pentingnya Hakim dalam Peradilan Pidana, maka perlu diawasi kinerja nya agar tidak di intervensi ataupun menyimpang, dengan tujuan agar putusan nya adil dan tidak memihak.

\section{Permasalahan}

Memahami hal tersebut, maka permasalahan dalam tulisan ini adalah sebagai berikut : Bagaimanakah fungsi Yudisial menjaga kemandirian hakim menurut Undang-undang Dasar 1945.

\section{Tujuan Penulisan}

Adapun tujuan dari Penulisan ini adalah: untuk mengetahui fungsi yudisial terhadap Hakim, khususnya dalam Sistem Peradilan Pidana.

\section{Kemandirian Hakim Dalam Sistem Peradi- lan Pidana}

Didalam masyarakat yang teratur, terlebih di Negara Hukum pasti ditemukan adanya suatu sistem peradilan pidana. Adapun tugas dan kegunaannya tidak lain adalah untuk menentukan apakah seorang pelaku kejahatan itu bersalah atau tidak. Sebagai suatu Negara $\mathrm{Hu}-$ kum, dimana Negara hendak menghukum warga Negaranya yang terbukti melakukan suatu tindak pidana, maka tetap harus ada Due Process of Law atau proses hukum yang adil.

\footnotetext{
${ }^{*}$ Dosen Tetap Fakultas Hukum UKI Jakarta
} 
Proses hukum yang adil adalah bukti bahwa Negara tidak sewenang-wenang memperlakukan warga negaranya sekalipun pelanggar hukum. Dalam hal ini, Negara tetap tunduk kepada hukum yang dibuatnya, serta memastikan tidak adanya kesewenang-wenangan, dan mengakui adanya pemisahan kekuasaan di dalam Negara. Sebagai Negara Hukum, Indonesia telah mengakui sistem peradilan pidana, dimana sistem ini bekerja berdasarkan peraturan perundang-undangan.

Sejalan dengan itu, sistem peradilan pidana sering diartikan sebagai suatu sistem dalam suatu masyarakat untuk menanggulangi kejahatan. Menanggulangi disini berarti usaha untuk mengendalikan kejahatan agar berada dalam batas-batas toleransi msyarakat. Sistem ini dianggap berhasil apabila sebagian besar dari laporan maupun keluhan masyarakat yang menjadi korban kejahatan dapat diselesaikan dengan diajukannya pelaku kejahatan ke sidang pengadilan dan diputus bersalah serta mendapat pidana. $^{1}$ Sebagai suatu sistem, sistem ini bertujuan untuk : (a) mencegah masyarakat menjadi korban kejahatan; (b) menyelesaikan kasus kejahatan yang terjadi sehingga masyarakat puas, bahwa keadilan telah ditegakkan dan yang bersalah di pidana; (c) mengusahakan agar mereka yang pernah melakukan kejahatan tidak mengulangi lagi kejahatannya. $^{2}$

Memahami arti dan tujuan sistem peradilan pidana, dimana salah satu tujuan nya untuk menentukan seseorang itu bersalah dan menegakkan keadilan dengan menghukum pelaku kejahatan, maka nyatalah disitu peranan hakim. Dalam hal ini, hakim adalah benteng utama serta pengadil di dalam Negara hukum, dimana putusannya harus memberi rasa keadilan dan kenyamanan bahkan memberi citra kepada hukum. Sejalan dengan itu, besarnya harapan kepada hakim agar memutus perkara seadil-adilnya serta memenuhi rasa keadilan masyarakat, itu dapat terwujud bila didasarkan kepada kemadirian hakim. Dalam hal ini, haruslah berdasarkan kompetensi, indepedensi dan integritas serta karakter moral yang tinggi

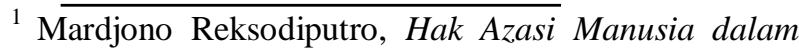
Sistem Peradilan Pidana (buku ketiga), Jakarta : Pusat Pelayanan keadilan dan Pengabdian Hukum, UI, 1994, hal 84.

${ }^{2}$ Ibid, hal 84-85
}

yang mampu untuk mewujud nyatakan Negara hukum. Sehingga dalam memeriksa dan memutus perkara, tidak dipengaruhi oleh kekuasaan dan politik.

Berkaitan dengan kemandirian hakim di suatu Negara yang menganut rule of law, seperti Indonesia, dimana: ${ }^{3}$ kebebasan kehakiman merupakan hal pokok yang ditentukan di dalam undang-undang, artinya kekuasaan kehakiman tidak boleh dipengaruhi oleh kekuasaan lain, bila pengadilan dipengaruhi instansi lain dalam pelaksanaan sistem peradilan pidana, hal ini akan mengalami titik rawan, karena dalam suatu Negara hukum, kekuasaan kehakiman tidak dapat dipengaruhi lembaga lain, hakim harus mandiri, sehingga keputusan mereka tidak saja bersifat tidak memihak secara pribadi tetapi juga tidak memihak di mata masyarakat. Posisi hakim sangat istimewa sehingga dapat dikatakan hakim adalah konkretisasi hukum dan keadilan yang abstrak. ${ }^{4}$

Sejalan dengan itu, hakim dalam menjalankan fungsinya tidak perlu ragu, sebab landasan hukum dalam menjalankan fungsinya dijamin oleh undang-undang. Landasan hukum wewenang hakim di dalam sistem peradilan pidana, antara lain dapat dilihat dalam Undangundang RI No 8 tahun 1981 tentang Hukum Acara Pidana, dan Undang-undang RI Nomor 14 tahun 1970 jo Undang-undang RI No 4 tahun 2004 tentang kekuasaan kehakiman. Undangundang RI No 8 Tahun 1981 tentang Kitab undang-undang Hukum Acara Pidana di pasal 1 butir 8 menyatakan : bahwa Hakim adalah pejabat peradilan Negara yang diberi wewenang oleh undang-undang untuk mengadili. Adapun yang dimaksud mengadili adalah serangkaian tindakan hakim untuk menerima,memeriksa dan memutus perkara pidana berdasarkan asas bebas, jujur dan tidak memihak di sidang pengadilan dalam hal dan menurut cara yang diatur dalam undang-undang.

Dari hal tersebut, maka tampak jelas bahwa wewenang hakim utamanya adalah me-

${ }^{3}$ Petrus Irwan Pandjaitan dan Charyah, Pidana Penjara dalam Perspektif Penegak hukum, Masyarakat, dan Nara Pidana, Jakarta : Ind Hill co, 2009, hal. 72

${ }^{4}$ Al Wisnu Subroto, Hakim dan Peradilan Indonesia, dalam beberapa aspek kebijakan sebagaimana dikutip oleh Petrus Irwan Pandjaitan dan Charyah dalam bukunya : Pidana Penjara dalam Perspektif Penegak Hukum, dan Masyarakat, Jakarta : Ind Hill co, 2009, hal. 72 
ngadili yang meliputi kegiatan-kegiatan menerima, memeriksa, dan memutus perkara pidana. Dalam hal ini, pedoman pokok nya adalah Kitab Undang-undang Hukum Acara Pidana yang dilandasi asas kebebasan, kejujuran, dan tidak memihak. Hakim memiliki kedudukan dan peranan yang penting demi tegaknya $\mathrm{Ne}$ gara hukum. Itulah sebabnya, Undang-undang Dasar 1945 mengatur secara khusus masalah kekuasaan kehakiman ini di pasal 24 dan pasal 25. Dalam hal ini ditegaskan bahwa kekuasaan kehakiman adalah kekuasaan yang merdeka, artinya lepas dari pengaruh pemerintah. Berhubung dengan itu, harus diadakan jaminan dalam undang-undang tentang kedudukan para hakim. ${ }^{5}$

Memahami hal tersebut, tampak jelas dasar bekerja nya hakim dalam peradilan pidana adalah untuk menjaga agar putusannya itu fair, jujur dan dapat diuji kebenarannya serta tidak boleh dipengaruhi oleh kepentingan-kepentingan karena uang, kekuasaan, pengaruh bahkan tekanan dari kekuasaan. Disamping itu juga, kemandirian hakim itu harus dapat di uji, dikritisi bahkan harus memiliki kebenaran dari segi hukum. Dengan demikian, putusan hakim itu dirasa memenuhi keadilan hukum di dalam masyarakat. Sejalan dengan itu juga, kemandirian hakim itu harus bebas memilih putusan yang akan dijatuhkan kepada pelaku kejahatan, sebab apa yang ada didalam undang-undang tidak selamanya dapat dirumuskan secara tepat.

Pada posisi inilah, hakim dituntut untuk menunjukkan keyakinan nya yang memang dijamin oleh undang-undang. Keyakinan Hakim sebagaimana diatur didalam Undang-undang RI No 8 tahun 1981 tentang Kitab Undang-undang Hukum Acara Pidana pada pasal 183 jelas menjadi bukti bahwa : hakim memiliki kekuatan, keyakinan, serta tanggung jawab terhadap apa yang diputuskannya. Sehingga menjadikannya seorang yang benar-benar menguasai perkara yang sedang dia periksa. Berkaitan dengan kemandirian hakim, dimana kebebasan kehakiman telah dibatasi dengan hukum dasar Negara "keadilan berdasarkan Pancasila" yakni keadilan yang tumbuh, hidup dan berkembang dalam masyarakat Indonesia sendiri, persoalannya bagaimanakah hakim menemukan-

\footnotetext{
${ }^{5}$ Rusli Muhammad, Sistem Peradilan Pidana Indonesia, Jogjakarta : UII Pres, 2011, hal. 25
}

nya untuk dapat diterapkan pada kasus konkrit ?. Dalam hubungan ini, Jimly Asshidiqie mengajukan tiga pertanyaan, pertama, apakah sesuatu yang popular dalam media massa dapat dikatakan sebagai cerminan dari rasa keadilan dalam seluruh masyarakat Indonesia. Kedua, apakah mungkin cita rasa masyarakat yang demikian majemuk seperti Indonesia dapat tercermin hanya dalam satu ekspresi tentang keadilan yang bersifat nasional? Ketiga, apakah cerminan rasa keadilan itu harus bersifat nasional atau harus lokal, yaitu terkait langsung dengan kasus demi kasus konkrit yang terjadi dalam masyarakat, sehingga perasaan keadilan yang hidup dalam masyarakat itu benar-benar dapat tercermin dalam putusan yang konkrit yang diterapkan hakim. Pertanyaan-pertanyaan ini adalah materi yang harus dijawab hakim dalam putusan-putusannya ketika mengadili perkara di pengadilan. ${ }^{6}$

\section{Fungsi Yudisial untuk Menjaga Kemandiri- an Hakim}

Sebagai Penegak hukum yang rentan terhadap pengaruh, baik politik dan kekuasaan serta suap, hakim harus dijaga dan dilindungi keberadaannya. Menjaga kemadirian hakim adalah mutlak dan perlu, mengingat apa yang diputuskan oleh hakim dalam putusannya, baik itu menghukum dan membebaskan pelaku kejahatan, maka itu sangat berimplikasi kepada nasib orang banyak, terlebih pelaku maupun korban. Putusan hukum oleh hakim yang didasarkan kepada kemadirian hakim tentunya menjadi harapan orang banyak, oleh karena itu, maka perlu pengawasan terhadap fungsifungsi Yudisial dalam konteks Peradilan Pidana, terlebih menjaga Indonesia adalah Negara Hukum.

Sebelum membahas mengenai fungsi yudisial itu lebih jauh, maka terlebih dahulu akan dikemukakan dasar dari diperkenalkannya fungsi yudisial melalui perubahan atau amandemen terhadap kekuasaan kehakiman sebagaimana dirumuskan dalam Pasal 24 UUD 1945, dimana Sebelum perubahan Undang-undang Dasar 1945, Bab tentang kekuasaan ke-

${ }^{6}$ Luhut M. P.Pangaribuan, Lay Judges \& Hakim Ad Hoc suatu studi Teoritis mengenai Sistem Peradilan Pidana Indonesia, Jakarta : Fakultas Hukum Pascasarjana UI dan Papas Sinar Sisanti, 2009, hal. 186187 
hakiman terdiri atas 2 (dua) Pasal yaitu Pasal 24 dan Pasal 25, setelah terjadi Amandemen, maka Bab tentang kekuasaan menjadi 5 (lima) Pasal, yaitu Pasal 24; Pasal 24-A; Pasal 24-B; Pasal 24-C; Pasal 24-D; dan Pasal 25. Pada perubahan ketiga (Tahun 2001) diputuskan Pasal 24 (kecuali ayat 3); Pasal 24-A; Pasal 24-B; Pasal 24-C; dan Pasal 24-D. Adapun Pasal 24 ayat (3) diputuskan pada Perubahan Keempat (Tahun 2002) sedangkan Pasal 25 tetap dipertahankan. Perubahan itu melahirkan dua lembaga baru dalam kekuasaan kehakiman yaitu Mahkamah Konstitusi (MK) dan Komisi Yudisial (KY). Secara umum, perubahan UUD 1945 itu dimaksudkan untuk memperkuat kekuasaan kehakiman dalam sistem ketatanegaraan Indonesia sebagai salah satu perwujudan ketentuan UUD 1945 yang menyatakan Indonesia adalah Negara hukum. ${ }^{7}$

Sebelum perubahan, ketentuan mengenai badan pelaksanaan kekuasaan kehakiman terdiri atas satu Pasal, yaitu Pasal 24 dengan dua ayat yaitu ayat (1) dan ayat (2). Setelah perubahan UUD 1945, materi ini tetap terdiri satu Pasal dan 3 (tiga) ayat, yaitu ayat (1), ayat (2) dan ayat (3). Pada perubahan ketiga (Tahun 2001) diputuskan dua ayat, yaitu ayat (1) dan ayat (2), sedangkan ayat (3) diputuskan pada perubahan keempat (Tahun 2002).Perubahan UUD 1945 dimaksudkan untuk mempertegas tugas kekuasaan kehakiman dan sistem ketatanegaraan Indonesia yakni untuk menyelenggarakan peradilan yang merdeka, bebas dari intervensi pihak manapun, guna menegakkan hukum dan keadilan.

Ketentuan ini merupakan perwujudan prinsip Indonesia sebagai Negara hukum sebagaimana ditegaskan oleh Pasal 1 ayat (3) UUD 1945. ${ }^{8}$ Sejalan dengan itu, Pada Pasal 24 ayat (2) dikatakan bahwa dibentuk suatu lembaga peradilan baru yakni Mahkamah Konstitusi (MK) disamping badan kehakiman yang telah ada, yaitu Mahkamah Agung (MA) dan badan peradilan yang berada di bawahnya yang kewenangannya diatur dalam Pasal 24-C. Perubahan atas amandemen UUD 1945 tidak semata ditujukan pada perubahan pada struktur dan kelembagaan kekuasaan kehakiman, namun sekaligus diarahkan pada peningkatan kualitas

\footnotetext{
${ }^{7}$ Latar Belakang, Proses dan Hasil Perubahan UUD 1945. Sekretariat Jenderal MPR RI 2003, hal. 190

${ }^{8}$ Ibid. hal. 193
}

fungsi-fungsi yudisial hakim dalam rangka menjaga kehormatan dan martabat hakim. Dalam Pada itu juga, Pasal 24-A ayat (2) UUD 1945 misalnya, secara tegas dirumuskan tentang martabat dan kehormatan hakim: "Hakim Agung harus memiliki integritas dan kepribadian yang tidak tercela, adil, professional, dan berpengalaman di bidang hukum". Demikian juga halnya dengan hakim-hakim konstitusi diberi amanat tentang kehormatan dan martabat, seperti dirumuskan dalam Pasal 24-C ayat (5): "Hakim konstitusi harus memiliki integritas dan kepribadian yang tidak tercela, adil, negarawan yang menguasai konstitusi dan ketatanegaraan, serta tidak merangkap sebagai pejabat Negara. Amanat yang sama juga ditujukan pada fungsi komisi yudisial yang mensyaratkan agar dalam pengusulan dan pengangkatan hakim agung memenuhi kriteria tentang kehormatan dan martabat.

Sejalan dengan itu pun, pada Pasal 24-B misalnya, secara tegas dirumuskan tentang salah satu kekuasaan komisi yudisial dalam rangka kehormatan dan martabat hakim, dikatakan: "komisi yudisial bersifat mandiri yang berwenang mengusulkan pengangkatan hakim Agung dan mempunyai wewenang lain dalam rangka menjaga dan menegakkan kehormatan, keluhuran martabat serta perilaku hakim". Dengan demikian, maka sangat tegas dinyatakan bahwa Hakim adalah penjaga atau benteng penjaga keadilan. Hakim sebagai penjaga hukum memiliki posisi terhormat dan mulia, karena memang perilaku sosialnya selalu diamati dan dinilai oleh masyarakat. Kehormatan yang dimiliki oleh hakim tentunya harus dilindungi agar tidak tercemar dan tercela akibat adanya perilaku hakim yang akhir-akhir ini mudah untuk "di suap" atau ditekan bahkan dipengaruhi oleh kekuasaan.Dalam hal itu juga, Hakim harus berani bersikap untuk tetap memegang prinsip bahwa keadilan itu bukan semata-mata berasal dari Undang-undang saja tapi keadilan itu dapat ditemukan dan dinyatakan oleh hakim melalui putusan-putusannya.

\section{Kehormatan Hakim Dalam Negara Hukum}

Negara Hukum dan Hakim adalah dua hal yang tidak terpisahkan, mengapa dikatakan demikian, hal ini dikarenakan bahwa implementasi dari Negara hukum itu ada pada diri Hakim. Dalam hal ini, hakimlah yang mewu- 
judkan hukum yang tercermin dalam setiap putusannya. Hakimlah yang menjadi representasi keadilan, siapapun tidak dapat membantah itu, bagaimana dan dimana itu dilaksanakan tentulah di pengadilan. Melalui pengadilan akan terbit putusan-putusan hukum yang menunjukkan adanya keadilan, dimana setiap warga Negara berhak untuk mendapatkannya.

Tanpa ada Negara hukum, maka hakim pun tidak akan ditemukan, karena segala sesuatunya akan diputuskan oleh "raja", "penguasa yang zalim" atau "diktator". Hakim tidak sekedar penegak hukum yang mengadili dan memutus seorang pelaku kejahatan semata, tapi dia juga adalah penemu hukum, manakalah undang-undang tidak mengatur apa yang sedang dipersengketakan oleh warga masyarakat. Dengan demikian, maka sangat mulia serta agung seorang hakim. Tidak ada yang menyangkal, kalau pun hakim itu menjadi tumpuan keadilan bagi orang yang tertindas hak-haknya, orang yang dirampas hak-haknya, bahkan kadangkala ada yang menganggap hakim itu seperti "Tuhan". Besarnya harapan dan mulianya keberadaan hakim oleh pencari keadilan dirasa bukan sesuatu yang berlebihan, mengingat hakim dapat membuat orang menjadi mati, orang menjadi bangkrut bahkan membuat orang menjadi menemukan harta miliknya yang sempat "hilang".

Berbagai ketentuan yang mengatur tentang kekuasaan kehakiman, didasari pemikiran bahwa hakim-hakim agung yang duduk di Mahkamah Agung dan hakim-hakim yang berada dalam lingkungan peradilan di bawahnya merupakan figur-figur yang sangat menentukan dalam perjuangan menegakkan hukum dan keadilan. Apalagi hakim agung dan para hakim adalah tumpuan harapan bagi pencari keadilan. ${ }^{9}$

Sebagai Negara hukum, masalah kehormatan dan keluhuran martabat, serta perilaku seluruh hakim merupakan hal yang sangat strategis untuk mendukung upaya menegakkan peradilan yang handal dan realisasi paham Indonesia adalah Negara hukum. Sudah tentu lembaga komisi yudisial menjadi lembaga yang dapat diharapkan memilih hakim agung dan akan berimplikasi pada pemilihan hakim-hakim di lingkungan peradilan oleh Mahkamah

${ }^{9}$ Ibid. hal. 198
Agung untuk mewujudkan penegakan hukum dan pencapaian keadilan melalui putusan hakim yang terjaga kehormatan dan keluhuran martabat serta perilakunya. Kedudukan hakim sedemikian penting dan strategis dalam peradilan maupun pengadilan. Peradilan menunjuk kepada proses pengadili, sedang pengadilan merupakan satu lembaga dalam proses tersebut. Lembaga-lembaga lain yang terlibat dalam proses mengadili adalah kepolisian, kejaksaan dan advokat. Hasil akhir dari proses peradilan tersebut berupa putusan pengadilan, atau sering juga digunakan kata putusan hakim, oleh karena hakimlah yang memimpin sidang di pengadilan. ${ }^{10}$

Berkaitan dengan itu, bila dilihat dari perspektif ilmu hukum, maka bagian penting dalam proses mengadili terjadi pada saat hakim memeriksa dan mengadili suatu perkara. Pada dasarnya yang dilakukan oleh hakim adalah memeriksa kenyataan yang terjadi, serta menghukum pelaku berdasarkan bukti-bukti serta didasari oleh undang-undang yang berlaku. Dalam hal ini, maka pada saat hakim memutuskan tentang bagaimana atau apa hukum yang berlaku untuk suatu kasus, maka pada waktu itulah penegakan hukum mencapai puncaknya. Dengan demikian, pada saat Putusan hakim itu dibacakan serta didengar oleh para pihak, maka hal itu lazim dianggap sebagai simbol puncak penegakan hukum, itu sebabnya peran dan kedudukan hakim menjadi sangat sentral dalam pemknaan keadilan.

Apa yang menjadi puncak penegakan hukum, oleh Max Weber disebutkan, "bahwa hakim adalah orang-orang yang bijaksana" dengan memberi istilah "Kadijustiz" yang diartikan sebagai para hakim yang tidak berorientasi kepada peraturan-peraturan hukum formal, tetapi mengambil putusan atas dasar-dasar dan azas-azas etika, agama, politik serta pola-pola kebiasaan di dalam masyarakat. ${ }^{11}$ Dalam hal ini keputusan hakim tidak semata mengandalkan prosedural hukum, tetapi lebih menekankan pada substansi hukum, itu sebabnya Max Weber menyebut hakim sebagai "orang-orang bijaksana". ${ }^{2}$

\footnotetext{
${ }^{10}$ Satjipto Rahardjo, Ilmu Hukum, Bandung: PT. Citra Aditya Bakti. 2000, hal. 182

$11 \ldots$, Hukum, Masyarakat dan Pembangunan. Bandung: Alumni, 1976, hal. 112

${ }^{12}$ Ibid., hal. 115
} 
Apa yang dikatakan Weber serta dikaitkan dengan perspektif praktik hukum, maka, putusan-putusan pengadilan selalu dianggap dan disimbolkan sebagai lambang keadilan. Berbeda halnya dengan kedudukan para penegak hukum lainnya, seperti jaksa, pengacara, dan Polisi sering dianggap sebagai para birokrat hukum yang semata-mata melakukan fungsi sebagai aparat birokrasi penyelenggara proses peradilan.Dalam pada itu juga, perlu pula melihat padangan Lawrence Friedman, yang memang tidak khusus menempatkan posisi hakim sebagai kunci bekerjanya sistem hukum, kecuali menganggapnya sama seperti aparat hukum lainnya. Hal ini karena Friedman hanya melihat dari sudut bekerjanya sebuah sistem hukum. Sistem hukum yang dimaksud adalah sistem yang terdiri atas tiga elemen atau unsur penting yakni: 1) substansi hukum, 2) struktur hukum dan 3) budaya hukum. ${ }^{13}$ Namun kalau dikaitkan teori Friedman, khususnya unsur budaya hukum atau legal culture sebagai potensi menggerakkan kesadaran hukum sekaligus pertimbangan hakim dalam memutus perkara, maka tampak ada benang merah antara pandangan Max Weber dan Friedman dalam soal bekerjanya sistem hukum harus berorientasi pada keadilan dan menggali azas-azas etika, agama, serta pola-pola kebiasaan dalam masyarakat. Apa yang mau disampaikan melalui pendapat Max Weber dan Friedman di atas adalah, bahwa sistem hukum harus ditujukan demi keadilan, dan keadilan dapat dilihat dari putusan-putusan hakim melalui pengadilan dimana hakim sebagai salah satu aparat penegak hukum menjadi kunci bagi tercapainya keadilan bagi masyarakat. Dalam hal ini keadilan bagi masyarakat menjadi taruhan kehormatan hakim dalam Negara hukum yang bermartabat.

\section{Negara Hukum Bermartabat}

Sebagai Negara Hukum, Indonesia menginginkan adanya badan peradilan yang mandiri dan berwibawa, untuk mewujudkan hal itu adalah dengan merumuskannya di dalam konstitusi. Sebagai Negara demokrasi, Indonesia telah mengalami berbagai perubahan atau amandemen terhadap Undang-undang Dasar 1945 yang makna dan tujuan nya adalah agar

\footnotetext{
${ }^{13}$ Lawrence Friedman, Teori dan Filsafat Hukum, Te laah Kritis atas Teori-teori Hukum. Jakarta: Rajawali Pers. 1990. Cet. I, hal. 29
}

Negara hukum yang sesungguhnya itu dapat terlihat dengan memberi tempat kepada kekuasaan kehakiman agar mandiri. Kemandirian Hakim tentunya menjadi cita-cita pendiri Negara dan seluruh rakyat sebagai warga Negara, betapa dikatakan demikian, karena hanya di Negara dimana hukum itu sebagai paling tertinggi keberadaannya, sehingga yang namanya politik dan kekuasaan harus tunduk.

Kenyataan paling mendasar di Indonesia saat ini, sepertinya Negara hukum itu hanyalah simbol atau "isapan jempol" semata, dimana banyak hakim yang tidak menggambarkan sikap kemandirian dan moralitasnya, hal itu dapat dilihat pada banyaknya hakim menjadi sasaran penegakan hukum dari institusi penegak hukum seperti Komisi Pemberantasan Korupsi, karena tersangkutnya hakim yang menerima suap.

Keterlibatan hakim dalam berbagai kasus suap menandakan hukum itu dapat "diperjualbelikan", bahkan hal ini sangat menyedihkan dan tragis, dimana seharusnya hakim itu menjadi perawat dan penjaga hukum di Negara hukum, justru hakim jualah yang "menghacurkannya". Kesedihan dan kepiluan masyarakat akibat diperlakukan sewenang-wenang serta banyaknya orang yang berperkara, tidak tahu lagi harus kemana mencari keadilan, karena memang keadilan di pengadilan pun sudah tidak ditemukan kecuali dengan "uang". "Ambruknya" wibawa hakim, menjadi salah satu indikator bahwa Negara hukum tidak lagi dapat dipertahanankan. Sejalan dengan itu, perlu menjaga dan melindungi kemandirian hakim.

Sejalan dengan keberadaan dan kenyataan hakim Indonesia saat ini serta pernyataan Indonesia sebagai Negara hukum, yang dapat dilihat pada Pasal 1 ayat (3) dengan rumusan yang menyatakan bahwa : "Negara Indonesia adalah Negara hukum". Dimana Ketentuan ini berasal dari penjelmaan dari Undang-undang 1945, yang secara tegas dikatakan atau yang dimaksud adalah Negara yang menegakkan supremasi hukum untuk menegakkan kekuasaan dan keadilan dimana tidak ada kekuasaan yang tidak dipertanggungjawabkan. Hal ini menunjukkan bahwa kekuasaan itu harus tunduk kepada Hukum. Menyinggung soal kekuasaan harus tunduk pada hukum, maka itu pun berarti bahwa siapun pun yang melanggar hukum harus dimintakan pertanggung jawabannya se- 
cara hukum, dan yang menyatakan seseorang tersebut pelanggar hukum adalah Hakim. Masuknya rumusan ini di Pembukaan Undang-undang dasar 1945 merupakan kesepakatan dasar untuk memasukkan hal-hal normatif dalam penjelasan pasal-pasal atau batang tubuh UUD 1945. ${ }^{14}$ Dalam penjelasan UUD 1945 rumusan lengkapnya adalah: "Negara yang berdasar atas hukum".

Dari hal tersebut nampak secara jelas bahwa Negara hukum oleh para pendiri dan legislator menjadi tujuan utama dari Negara Indonesia. Dimana, Secara umum, dalam setiap Negara yang menganut paham Negara hukum, kita melihat bekerjanya tiga prisnsip dasar, yaitu: supremasi hukum (supremacy of law), kesetaraan di hadapan hukum (equality before the law), dan penegakan hukum dengan cara-cara yang tidak bertentangan dengan hukum (due process of law). Dalam setiap Negara hukum akan tampak ciri-ciri sebagai berikut:

1. Adanya legalitas dalam arti hukum yaitu baik pemerintah/Negara maupun warga Negara dalam bertindak harus berdasar atas dan melalui hukum.

2. Adanya kekuasaan kehakiman atau peradilan yang merdeka.

3. Adanya peradilan tata usaha Negara.

4. Adanya jaminan perlindungan hak-hak azasi manusia. $^{15}$

Melalui prinsip-prinsip di atas secara tegas dicirikan bahwa kedudukan hakim demikian pentingnya dalam konsep Negara hukum. Hakim memiliki kekuasaan secara konstitusional, sehingga dapat diartikan bahwa tanpa kekuasaan kehakiman maka tidak ada Negara yang menyebutkan diri sebagai Negara hukum. Begitu besarnya kekuasaan kehakiman tersebut tentu harus diikuti dengan menjaga kehormatan dan kemandirian hakim. Hanya dengan melindungi serta menjaga Hakim, maka moralitas hakim di dalam Negara hukum itu akan terlihat. Menjaga dan melindungi kemandirian hakim tentunya tidak sekedar melalui undangundang semata, tapi perlu perlindungan secara menyeluruh, baik dari segi keamanan, penga-

\footnotetext{
${ }^{14}$ Mahfud. MD, Politik Hukum di Indonesia. Jakarta: Raja Grafiando Persada, 2012. hal. 37

${ }^{15}$ Daniel. S.Lev. Hukum dan Politik di Indonesia, Keseimbangan dan Perkembangan, Jakarta: LP3S. Cet. Ketiga. 2013, hal. 217
}

wasan, serta seleksi penerimaan, dan fasilitas yang tersedia bahkan kalaupun masa kerjanya pun perlu diperpanjang sampai usia tertentu yang tidak dibatasi seperti sekarang ini. Hal terakhir ini, sepertinya dilupakan oleh pemerintah Indonesia. Dengan demikian, Negara dapat menuntut hal yang lebih baik dari hakim Indonesia. Keberadaan Indonesia sebagai Negara Hukum dapat terjaga dan terus berlaku, bila memang Hakim menyadari bahwa merekalah yang menjadi benteng Negara Hukum yang bermartabat.

\section{Kesimpulan}

Fungsi-fungsi yudisial hakim diatur dan diamanatkan secara tegas oleh UUD 1945, baik terhadap hakim agung maupun hakim dalam lingkungan peradilan di bawah Mahkamah Agung. Kedudukan hakim sedemikian pentingnya dalam sistem hukum maupun dalam proses peradilan, sehingga kehormatan hakim perlu dijaga dan dilindungi.

\section{Saran}

Seluruh rangkaian sistem hukum dan proses peradilan akan bermuara dan mengalami puncaknya pada putusan-putusan hakim melalui peradilan, bahkan sosok hakim sering ditampilkan sebagai simbol keadilan. Sudah sepatutnya hakim itu harus dijaga dan dilindungi kemandiriannya melalui peraturan perundang-undangan. 


\section{Daftar Pustaka}

Daniel. S. Lev. Hukum dan Politik di Indonesia.Kesinambungan dan Perkembangan, Jakarta: LP3S. 2013.

Lawrence Friedman.Teori dan Filsafat Hukum. Jakarta: Rajawali Pers.

1990. Mahfud. MD.Politik Hukum di Indonesia, Jakarta : LP3ES, 2009

Maurice Duverger.Sosiologi Politik. Jakarta: Obor Ilmu. 1976

Satjipto Rahardjo.Hukum, Masyarakat dan Pembangunan. Bandung: Alumni 1976 . Ilmu Hukum. Bandung: Citra Aditya Bakti, 2000

Latar Belakang, Proses dan Hasil Perubahan UUD 1945. Sekretariat Jenderal MPR RI. Jakarta 2003 Mardjono Reksodiputro, Hak azasi Manusia dalam sistem Peradilan Pidana (buku ketiga), Jakarta :

Pusat Pelayanan Keadilan dan Pengabdian Hukum, UI, 1994

Petrus Irwan Pandjaiatan dan Charyah, Pidana Penjara dalam Perspektif Penegak Hukum, Masyarakat dan Narapidana, Jakarta : Ind Hill co, 2009

Luhut M.P. Pangaribuan, Lay Judges\& Hakim Ad Hoc suatu studi Teoritis Mengenai Sistem Peradilan Pidana Indonesia, Jakarta : Fakultas Hukum UI dan Papas Sinar santi, 2009

Rusli Muhammad, Sistem Peradilan Pidana Indonesia, Jogjakarta : UII Press, 2011 